\title{
PENERAPAN PEMBELAJARAN MATEMATIKA REALISTIK UNTUK MENINGKATKAN KEMAMPUAN PEMAHAMAN MATEMATIS SISWA PADA MATERI BENTUK ALJABAR DI KELAS VII SMP
}

\author{
Nurvitri Sinaga \\ Universitas Katolik Santo Thomas, Medan; \\ nurvitrisinaga92@gmail.com
}

\begin{abstract}
Abstrak. Penelitian ini bertujuan untuk mengetahui tingkat kemampuan pemahaman matematis siswa sebelum dan sesudah penerapan pembelajaran matematika realistik dan untuk mendeskripsikan penerapan pendekatan pembelajaran matematika realistik di SMP Negeri 3 Siempat Nempu Hilir pada materi bentuk aljabar. Jenis penelitian ini adalah Penelitian Tindakan Kelas. Subjek penelitian adalah siswa kelas VII SMP Negeri 3 Siempat Nempu Hilir tahun ajaran 2017/2018 yang berjumlah 30 orang. Hasil penelitian ini menunjukkan bahwa tingkat pemahaman matematis siswa di kelas VII-C SMP Negeri 3 Siempat Nempu Hilir sebelum dan sesudah penerapan Pembelajaran Matematika Realistik meningkat. Penerapan pendekatan pembelajaran matematika realistik diterapkan dalam beberapa langkah yaitu pertama, memberikan masalah kontekstual. Kedua, menjelaskan masalah kontekstual. Ketiga, menyelesaikan masalah kontekstual. Keempat, mendiskusikan jawaban. Kelima, menyimpulkan. Pelaksanaan pendekatan pembelajaran matematika realistik di SMP Negeri 3 Siempat Nempu Hilir pada materi bentuk aljabar sudah tergolong baik.
\end{abstract}

Kata Kunci. Pemahaman matematis, matematika realistik, bentuk bentuk aljabar

\begin{abstract}
This study aims to determine the level of mathematical understanding ability of students before and after the application of realistic mathematics learning and to describe the application of the Realistic Mathematics Learning approach at Nempu Hilir State Middle School 3 in the algebraic material form. This type of research is Classroom Action Research. The research subjects were seventh grade students of State Junior High School 3 Siempat, Nempu Hilir 2017/2018 Academic Year, amounting to 30 people. The results of this study indicate that the level of mathematical understanding of students in class VII-C
\end{abstract}

Cartesius: Jurnal Pendidikan Matematika Vol. 1, No. 1

CProdi Pendidikan Matematika Universitas Katolik Santo Thomas 
State Junior High School 3 Siempat Nempu Hilir before and after the application of Realistic Mathematics Learning increased. The application of realistic mathematical learning approaches is applied in several steps, namely first, providing contextual problems. Second, explain contextual problems. Third, resolve contextual problems. Fourth, discuss answers. Fifth, conclude. The implementation of a realistic mathematics learning approach in the State Junior High School 3 Siempat of Nempu Hilir in the algebraic form material has been classified as good.

Keywords. Mathematical understanding, realistic mathematics, algebra form

\section{PENDAHULUAN}

Matematika merupakan salah satu mata pelajaran yang sangat penting dalam dunia pendidikan karena Matematika berkenan dengan ide-ide, struktur- struktur dan hubungan-hubungannya yang diatur menurut urutan yang logis. Jadi dapat dikatakan bahwa matematika berkenaan dengan konsep-konsep yang abstrak. Berkenaan dengan struktur abstrak, maka tidak jarang siswa atau mahasiswa mengalami kesulitan dalam memahami matematika atau bahkan dalam menyelesaikan soal-soal matematika di sekolah ataupun di tingkat perguruan tinggi [1]. Pembelajaran matematika memiliki peranan penting dalam kehidupan sehari-hari. Dalam materi matematika yang diajarkan memiliki peranan penting dalam menyelesaikan persoalan dalam kehidupan sehari-hari, oleh karena itu siswa diberikan dasar- dasar untuk memahami matematika ini [2]. Dengan melihat hal ini, maka matematika ditetapkan sebagai salah satu mata pelajaran wajib dalam setiap Ujian Nasional serta dilihat dari jumlah jam mata pelajaran matematika yang lebih banyak.

Dengan belajar matematika, siswa diharapkan mampu melatih cara berpikir, mengembangkan aktivitas kreatif, mengembangkan kemampuan memecahkan masalah dan mampu menerapkan penggunaan suatu rumus sesuai pemahaman matematis siswa dalam menjelaskan suatu gagasan. Dalam pembelajaran matematika, siswa tidak hanya diajarkan untuk sekedar menghafal rumus matematika namun harus mampu dan paham untuk menggunakan rumus tersebut. Kelemahan pembelajaran matematika saat

Cartesius: Jurnal Pendidikan Matematika Vol. 1, No. 1

CProdi Pendidikan Matematika Universitas Katolik Santo Thomas 
ini para siswa tidak dapat menghubungkan konsep-konsep matematika di sekolah dengan pengalaman mereka sehari-hari. Pembelajaran matematika terlalu formal, kurang mengkaitkan dengan makna, pemahaman, dan aplikasi dari konsep-konsep matematika, serta gagal dalam memberikan perhatian yang cukup terhadap kemampuan penalaran dan pemecahan masalah. Hasil-hasil riset dalam pembelajaran matematika menunjukkan bahwa pendekatan kontruktivisme merupakan kunci untuk membangun pemahaman matematika yang mendalam.[3].

Berdasarkan observasi yang telah dilakukan di SMP Negeri 3 Siempat Nempu Hilir bahwa proses pembelajaran masih berpusat kepada guru, guru masih cenderung menyampaikan materi dengan metode ceramah sehingga siswa merasa bosan dan membuat siswa menjadi pasif. Guru juga kurang melibatkan siswa sehingga siswa tidak aktif dalam pembelajaran. Hal ini menyebabkan siswa sulit untuk memahami materi. Berdasarkan hal tersebut di atas, maka penulis ingin mengetahui kemampuan pemahaman matematis siswa dengan memberikann 5 butir soal tes kemampuan pemahaman matematis di kelas VII-C SMP Negeri 3 Siempat Nempu Hilir pada tanggal 11 maret 2017. Dari hasil analisis jawaban siswa diperoleh rata rata nilai kemampuan pemahaman matematis siswa sebesar 31,3 dengan nilai tertinggi 80 dan nilai terendah 0 . Dari 30 siswa tidak ada siswa yang mendapat nilai diantara 81-100 dengan kategori sangat baik, 1 orang atau 3,3\% siswa mendapat nilai antara 61-80 dengan kategori baik, 8 orang atau 26,7\% siswa mendapat nilai antara 41-60 dengan kategori cukup baik, 10 orang atau $33,3 \%$ siswa mendapat nilai antara 21-40 dengan kategori kurang baik, dan 11 orang atau 36,7\% siswa mendapat nilai atara 0-20 dengan kategori sangat tidak baik. Hal ini menunjukkan bahwa tingkat kemampuan pemahaman matematis siswa kelas VII-C SMP Negeri 3 Siempat Nempu Hilir masih sangat rendah, oleh karena itu kemampuan pemahaman matematis siswa perlu diperbaiki.

Kemampuan pemahaman matematis merupakan kemampuan yang sangat penting untuk menunjang keberhasilan pembelajaran. Untuk dapat memiliki kemampuan pemahaman maka guru harus mampu menghubungkan materi matematika dalam kehidupan sehari-hari. Pendekatan pembelajaran tersebut 
adalah pendekatan pembelajaran matematika realistic. Realistic Mathematic Education (RME) merupakan salah satu pendekatan pembelajaran matematika yang berorientasi pada matematisasi pengalaman sehari- hari dan menerapkannya dalam kehidupan sehari-hari [4].

\section{METODE}

Penelitian ini merupakan Penelitian Tindakan Kelas (Classroom Action Research) untuk mengetahui tingkat kemampuan pemahaman matematis siswa dan mendeskripsikan penerapan pendekatan Pembelajaran Matematika Realistik. PTK ialah suatu penelitian yang dilakukan secara sistematis reflektif terhadap berbagai tindakan yang dilakukan oleh guru yang sekaligus sebagai peneliti, sejak disusunnya suatu perencanaan sampai penilaian terhadap tindakan nyata di dalam kelas yang berupa kegiatan belajar-mengajar, untuk memperbaiki kondisi pembelajaran yang dilakukan [5].

Penelitian dilaksanakan di SMP Negeri 3 Siempat Nempu Hilir Kabupaten Dairi semester ganjil tahun ajaran 2017/2018 berjumlah 30 orang siswa. Objek penelitian ini adalah peningkatan kemampuan pemahaman matematis pada materi bentuk aljabar di kelas VII SMP Negeri 3 Siempat Nempu dengan penerapan Pendekatan Pembelajaran Matematika Realistik.

Data yang diperoleh dalam penelitian ini adalah kemampuan pemahaman matematis siswa pada materi bentuk aljabar yang diperoleh dari tes uraian dengan indikator kemampuan pemahaman matematis siswa. Keberhasilan penelitian ini sesuai dengan indikator kinerja yang sudah ditetapkan yaitu (1) indikator keberhasilan kualitas proses pembelajaran minimal "baik" menggunakan instrument lembar observasi aktivitas guru, (2) indikator keberhasilan perbaikan perilaku siswa minimal "baik". Data ini diperoleh dari lembar aktivitas guru dan (3) indikator keberhasilan hasil belajar secara klasikal minimal 75\% dari jumlah siswa yang mencapai KKM yang ditetapkan". Hal ini diperoleh dari hasil tes kemampuan pemahaman matematis siswa.

Cartesius: Jurnal Pendidikan Matematika Vol. 1, No. 1

CProdi Pendidikan Matematika Universitas Katolik Santo Thomas 


\section{HASIL DAN PEMBAHASAN}

\section{HASIL}

Berdasarkan hasil pengamatan peneliti dan diskusi dengan observer mulai dari siklus 1 sampai siklus 2 terdapat beberapa hal yang ditemukan saat pembelajaran berlangsung, yaitu:

\section{Penerapan Metode Problem Solving}

Sebelum siklus I dimulai, siswa diberikan tes pengetahuan materi prasyarat. Gambaran umum hasil tes pengetahuan materi prasyarat pada materi pecahan dengan rata-rata nilai 57 dengan jumlah siswa yang memiliki kemampuan pemahaman matematis 8 orang $(26,67 \%)$ dan yang masih belum memiliki kemampuan pemahaman matematis sebanyak 22 orang $(73,33 \%)$. Dengan demikian, seiring dengan berjalannya siklus 1 maka siswa yang belum memiliki penguasaan materi prasyarat harus dibimbing untuk meningkatkan pengetahuan materi prasyaratnya.

\section{SIKLUS 1}

\section{Perencanaan}

Tahapan pertama dalam perencanaan adalah menganalisis kurikulum yang digunakan di sekolah. Tahap selanjutnya adalah menyusun perangkat pembelajaran yang akan digunakan yaitu rencana pelaksanaan pembelajaran (RPP) yang sesuai dengan pendekatan pembelajaran matematika realistik dan Lembar Aktivitas Siswa (LAS) yang disusun berdasarkan indikator kemampuan pemahaman matematis. RPP yang disusun untuk dua kali pertemuan di siklus 1. Setelah menyusun perangkat pembelajaran selanjutnya adalah menyusun instrumen penelitian yaitu mulai dari menyusun kisi-kisi tes, pedoman penskoran, instrumen tes, lembar observasi aktivitas guru dan siswa.

\section{Pelaksanaan}

Pelaksanaan tindakan pada siklus 1 merupakan penerapan yang dilakukan terhadap rencana yang telah disusun. Tahapan pendekatan pembelajaran matematika realistik dilakukan dalam lima fase. Fase pertama, memberikan masalah kontekstual. Fase kedua, menjelaskan masalah kontekstual. Fase ketiga, menyelesaikan masalah kontekstual. Fase keempat, mendiskusikan jawaban. Fase kelima yaitu menyimpulkan. Hasil penelitian tindakan yang 
dianalisis secara deskriptif adalah persentase aktivitas guru dan siswa serta data hasil tes kemampuan pemahaman matematis siswa pada materi pecahan. Persentase lembar aktivitas siswa siklus 1 adalah 48 \% (kriteria cukup) dan persentase lembar aktivitas guru siklus 1 adalah $44 \%$ (kriteria cukup). Gambaran umum hasil tes kemampuan pemahaman matematis siswa siklus 1 diperoleh nilai tertinggi 82 dan nilai terendah 4 dengan ratarata nilai 57,33. Mengacu kepada nilai KKM 75, maka diperoleh 14 orang $(46,67 \%)$ siswa yang memiliki kemampuan pemahaman matematis dan yang belum memiliki kemampuan pemahaman matematis sebanyak 16 orang (53,33\%). Berdasarkan hasil perolehan ini maka secara kelompok (klasikal) dapat dikatakan siswa belum memiliki kemampuan pemahaman matematis pada materi aljabar.

\section{Observasi}

Observasi merupakan bagian dari proses pengumpulan data yang diperlukan dalam penelitian ini. Pengamatan dalam penelitian ini dilaksanakan ketika proses tindakan berlangsung yang dilakukan oleh observer. Observasi yang dilakukan meliputi monitoring pada proses pembelajaran matematika di kelas secara langsung. Kegiatan yang diamati meliputi aktivitas guru dan siswa dalam pembelajaran matematika realistik.

\section{Refleksi}

Kelemahan dari pelaksanaan pendekatan pembelajaran matematika realistik yang telah dilakukan adalah : Pertama, guru masih belum maksimal dalam mengamati siswa dalam belajar. Kedua, guru tidak memberikan penguatan kembali sehingga siswa siswa yang belum betul-betul paham hanya mengerti sampai disitu saja. Ketiga, sebagian besar siswa belum berani mempresentasikan hasil jawabannya. Keempat, aktivitas siswa yang dilakukan dalam pembelajaran belum berjalan dengan optimal karena sebagian besar siswa masih kesulitan mengerjakan LAS dan kelima, dalam mengerjakan soal pemahaman atau penerapan, sebagian besar siswa belum terbiasa untuk membuat model atau bentuk pemisalan meskipun guru selalu mengingatkan dan menganjurkan untuk membuat model (bentuk aljabar).

Dari berbagai kelemahan yang ditemui pada siklus 1, maka guru perlu melakukan upaya perbaikan terhadap pelaksanaan tindakan siklus 2.

Cartesius: Jurnal Pendidikan Matematika Vol. 1, No. 1

CProdi Pendidikan Matematika Universitas Katolik Santo Thomas 
Rencana tindakan yang dilakukan pada siklus 2 untuk mengatasi kelemahan pada siklus 1 adalah : pertama, pembelajaran dilakukan secara kelompok karena guru lebih mudah untuk berkeliling memperhatikan setiap siswa dalam kelompok dan sisiwa juga dapat berdiskusi dengan teman sehingga diharapkan dapat meningkatkan aktivitas siswa. Kedua, guru harus memberikan kesempatan kepada siswa dan setiap siswa harus terlibat dalam belajar dengan cara menunjuk siswa langsung yang maju dan harus berani mempresentasikan hasil jawabannya. Ketiga, memuji siswa yang maju, memberikan tepuk tangan.

Berdasarkan indikator kinerja, secara klasikal siswa masih belum memiliki kemampuan pemahaman matematis siklus 1 dan aktivitas guru dan siswa dalam lembar observasi belum mencapai kriteria minimal baik sehingga harus dilanjutkan ke siklus 2 dengan pendekatan pembelajaran matematika realistik dengan beberapa perbaikan sesuai dengan rencana tindakan siklus 2 yang telah diungkapkan.

\section{SIKLUS 2}

\section{Perencanaan}

Tahapan rencana siklus 2 menyiapkan RPP sesuai dengan perbaikan yang direncanakan sebelumnya, menyususn LAS, serta membuat instrumen tes yaitu kisi-kisi tes, pedoman penskoran tes, instrumen tes, lembar observasi aktivitas guru dan sisiwa. Pelaksanaan tindakan yang akan dilakukan disesuaikan perbaikan tindakan yang dinyatakan sebelumnya di tahap refleksi siklus 1 .

\section{Pelaksanaan}

Pelaksanaan tindakan pada siklus 2 merupakan penerapan yang dilakukan terhadap rencana yang telah disusun sebelumnya dalam penerapan pendekatan pembelajaran matematika realistik sesuai dengan perbaikan terhadap kelemahan siklus 1. Hasil penelitian tindakan yang dianalisis secara deskriptif adalah persentase aktivitas guru dan siswa serta data hasil tes kemampuan pemahaman matematis siswa pada materi pecahan. Persentase lembar aktivitas siswa siklus 2 adalah $70 \%$ (kriteria baik) dan persentase lembar aktivitas guru siklus 1 adalah $73 \%$ (kriteria baik). Gambaran umum hasil tes kemampuan pemahaman matematis siswa siklus 
1 diperoleh nilai tertinggi 100 dan nilai terendah 50 dengan rata-rata nilai 80 . Mengacu kepada nilai KKM 75, maka diperoleh 25 orang (83,33 \%) siswa yang memiliki kemampuan pemahaman matematis dan yang belum memiliki kemampuan pemahaman matematis sebanyak 5 orang (16,67 \%). Berdasarkan hasil perolehan ini maka secara kelompok (klasikal) dapat dikatakan siswa sudah memiliki kemampuan pemahaman matematis pada materi bentuk aljabar.

\section{Observasi}

Berdasarkan hasil observasi yang dilakukan pada siklus 2 diperoleh gambaran bahwa siswa sudah berani mengutarakan pendapatnya. Ketika dalam tahap diskusi siswa mampu untuk saling memberikan idenya msingmasing dan berani untuk mengutarakan hasil diskusinya.

\section{Refleksi}

Secara garis besar pelaksanaan pembelajaran pada siklus 2 sudah lebih baik dari pada siklus 1 . Rencana perbaikan di siklus 2 sudah dilaksanakan dengan baik sehingga hambatan-hambatan yang terjadi pada siklus 1 dapat diminimalkan pada siklus 2. Sebagian besar siswa sudah terbiasa menyelesaikan soal penerapan yang berbentuk soal cerita dengan langkahlangkah yang sesuai. Siswa sudah mampu membuat model matematika untuk mengerjakan soal bentuk aljabar sesuai dengan permintaan soal yang ditentukan. Berdasarkan indikator kinerja, secara klasikal siswa sudah memiliki kemampuan pemahaman matematis siklus 2 dan aktivitas guru dan siswa dalam lembar observasi aktivitas guru dan sisiwa sudah mencapai kriteria minimal baik sehingga siklus dapat dihentikan

\section{PEMBAHASAN}

\section{Peningkatan Pemahaman Matematis Siswa}

Peningkatan kemampuan pemahaman matematis siswa dapat dilihat berdasarkan hasil tes pemahaman matematis setiap siklus. Berdasarkan nilai yang diperoleh dari tes pengetahuan materi prasyarat dan tes setiap siklus yaitu siklus 1 dan siklus 2 bahwa terjadi peningkatan belajar yang dilihat secara klasikal, yaitu dari 26,67\% menjadi 46,67\% kemudian pada tes terakhir pada siklus 2 menjadi 83,33\%. Untuk lebih jelasnya dapat dilihat diagram 
dibawah ini.

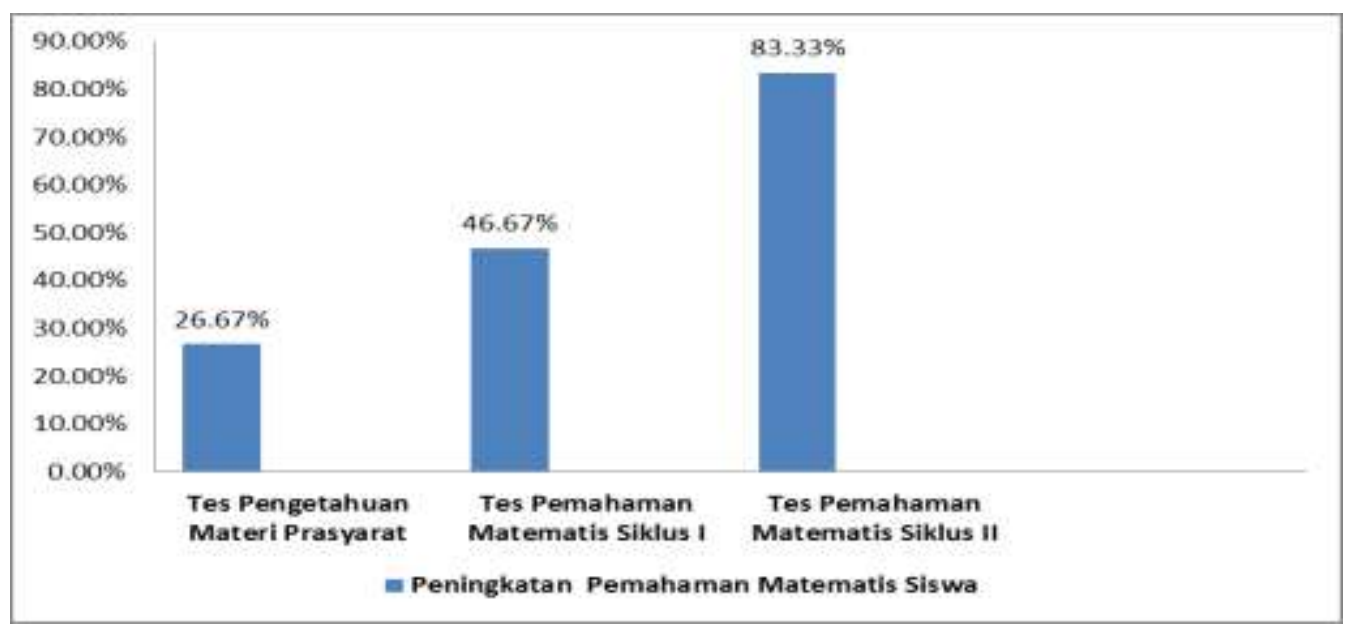

Gambar 1. Kemampuan Pemahaman Matematis Siswa Secara Klasikal

Gambar 1 di atas menunjukkan bahwa pendekatan Pembelajaran Matematika Realistik dapat meningkatan pemahaman matematis siswa pada materi bentuk aljabar di kelas VII-C SMP Negeri 3 Siempat Nempu Hilir.

\section{Penerapan Pembelajaran Matematika Realistik}

Penelitian yang dilaksanakan adalah Penelitian Tindakan Kelas (PTK) dengan menerapkan pendekatan Pembelajaran Matematika Realistik. Pembelajaran dilaksanakan dua siklus yang masing-masing siklus terdiri dari dua pertemuan. Guru menerangkan materi dengan memberikan terlebih dahulu masalah kontekstual seperti benda-benda nyata yang ada disekitar. Tahap perencanaan tindakan siklus 1 dan siklus 2 sama dan sesuai dengan fase-fase dalam Pembelajaran Matematika Realistik, yang membedakan adalah pelaksanaan dalam proses belajar.

Pembelajaran pada siklus 1 dilaksanakan secara individu. Individu yang dimaksud adalah bahwa tidak ada berlangsung belajar kelompok. Dalam siklus 1 penerapan Pembelajaran Matematika Realistik berjalan lancar namun masih banyak proses belajar guru dan siswa yang belum tercapai. Pada fase pertama, memberikan masalah kontekstual. Siswa masih sangat kurang dalam memahami masalah dalam LAS. Kedua, menjelaskan masalah kontekstual. Disini guru masih belum memberikan kesempatan bertanya kepada siswa yang belum memahami masalah. Siswa belum mampu menyelesaikan permasalahan dengan pengetahuan yang mereka miliki.

Cartesius: Jurnal Pendidikan Matematika Vol. 1, No. 1

CProdi Pendidikan Matematika Universitas Katolik Santo Thomas 
Ketiga, menyelesaikan masalah kontekstual. Guru tidak mengamati siswa dan kurang memfasilitasi apa kendala yang dihadapi siswa sehingga siswa belum mampu merumuskan model of dan cara penyelesaian dari masalah kontekstual. Keempat, Mendiskusikan jawaban. Sebagian besar siswa tidak berani untuk mempersentasikan hasil jawabannya sehingga proses tanya antara siswa tidak berlangsung dengan baik, dan pada fase ini siswa masih kewalahan dalam mendiskusikan jawaban. Kelima, menyimpulkan. Dalam menyimpulkan guru kurang melibatkan siswa untuk menyampaikan kesimpulan yang mereka buat dan akhirnya siswa tidak ada memperbaiki hasil belajar yang belum sesuai di kelas.

Siklus 2 dilakukan ketika siklus 1 belum tercapai. Untuk siklus 2 tetap melakukan langkah-langkah pada siklus 1. Pada siklus 2 dilakukan proses belajar secara kelompok yang terdiri dari 5 orang setiap kelompok. Penerapan Pembelajaran Matematika Realistik pada siklus 2 berjalan lancar dan lebih baik dibandingkan siklus 1. Dari hasil observasi menunjukkan bahwa dari setiap fase yaitu mulai fase pertama yaitu memberikan masalah kontekstual sampai fase kelima yaitu menyimpulkan mengalami perubahan yang baik. Siswa juga aktif dalam hal mendengarkan dan menanggapi guru karena dilakukan belajar berkelompok, jadi sesama siswa saling membantu dan saling memberikan pendapatnya. Guru lebih melibatkan banyak siswa dalam belajar. Pada siklus ini siswa sudah berani mempersentasekan hasil diskusinya. Untuk itu pembelajaran atau tindakan berakhir sampai siklus 2 karena Pembelajaran Matematika Realistik sudah berjalan dengan baik sesuai tahapannya dan sudah mencapai indikator kinerja keberhasilan.

\section{KESIMPULAN}

Kesimpulan yang diperoleh yaitu bahwa penerapan pendekatan pembelajaran matematika realistik pada materi Aljabar dapat meningkatkan kemampuan pemahaman matematis siswa kelas VII-C SMP Negeri 3 Siempat Nempu Hilir dan pelaksanaan pembelajaran dengan pendekatan PMR sudah tergolong baik.

\section{UCAPAN TERIMAKASIH}

Terimakasih penulis sampaikan kepada program studi Pendidikan

Cartesius: Jurnal Pendidikan Matematika Vol. 1, No. 1

CProdi Pendidikan Matematika Universitas Katolik Santo Thomas 
Matematika Universitas Katolik Santo Thomas dalam hal ini dosen pembimbing 1 yaitu Ibu Imelda, S.Pd., M.Pd dan dosen pembimbing 2 yaitu Ibu Sinta Dameria Simanjuntak, S.Si., M.Pd. yang sudah membantu dalam penulisan skripsi dan artikel ini. Semoga hasil dari penelitian ini bermanfaat bagi perkembangan ilmu pengetahuan.

\section{DAFTAR PUSTAKA}

[1] I. Imelda, "Analisis Kesulitan Mahasiswa Dalam Menyelesaikan Soal Pemecahan Masalah Pada Mata Kuliah Aljabar dan Trigonmetri," vol. 4, no. 1, pp. 49-56, 2018.

[2] H. Kusmanto and I. Marliyana, "Pengaruh Pemahaman Matematika Terhadap Kemampuan Koneksi Matematika Siswa Kelas VII Semester Genap SMP Negeri 2 Kasokandel Kabupaten Majalengka," Eduma, vol. 3, no. 2, pp. 61-75, 2014.

[3] B. Murtiyasa, J. Pendidikan, M. Universitas, and M. Surakarta, “Tantangan pembelajaran matematika era global," no. 3, pp. 28-47, 2015.

[4] S. Fajar, "Pembelajaran Matematika Dengan Pendekatan Matematika Realistik di SMP. Yogyakarta:P4TK," pp. 1-10, 2010.

[5] M. H and P. Tedi, Penelitian Tindakan Kelas Teori dan Praktek, 2008. 